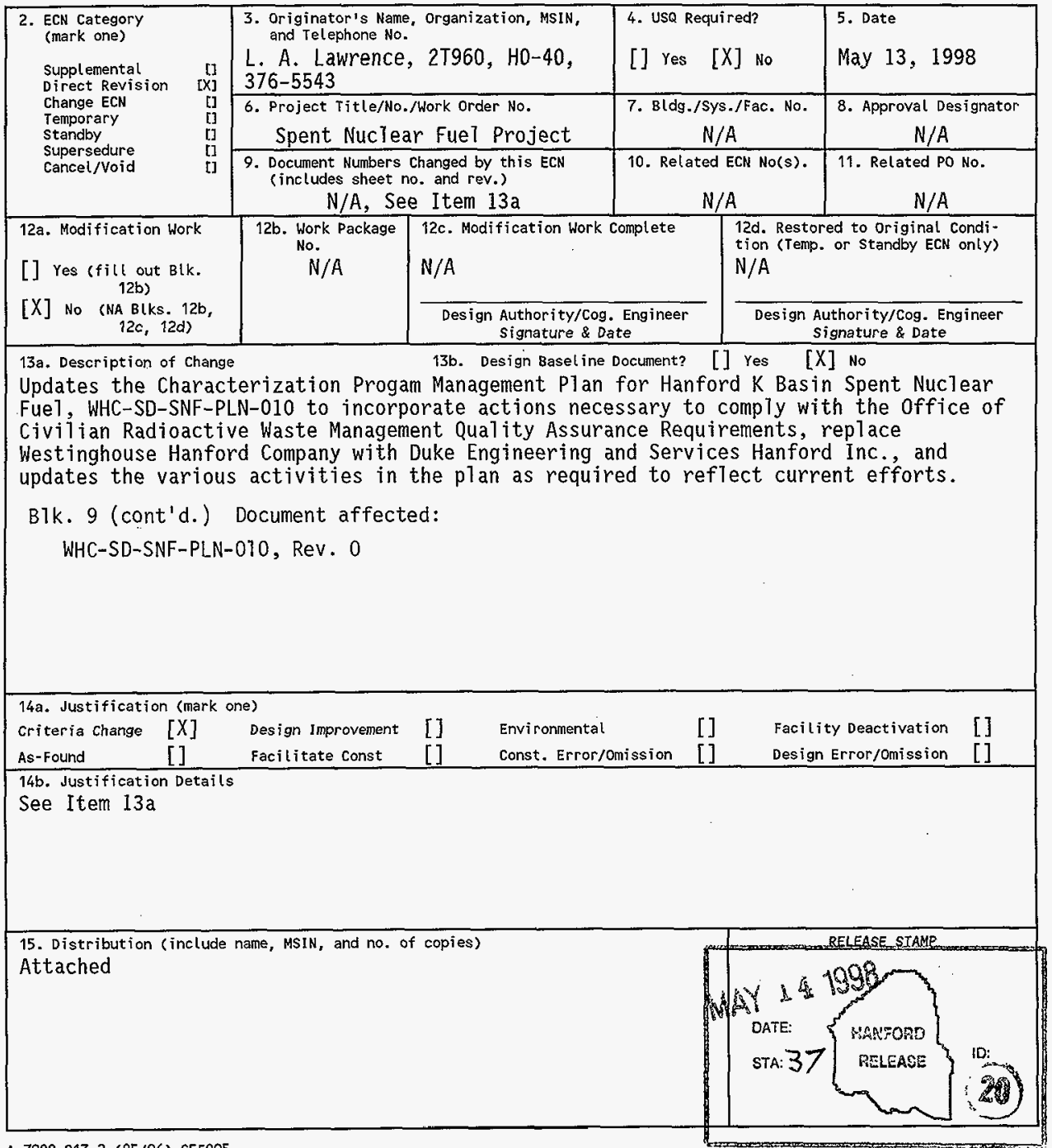




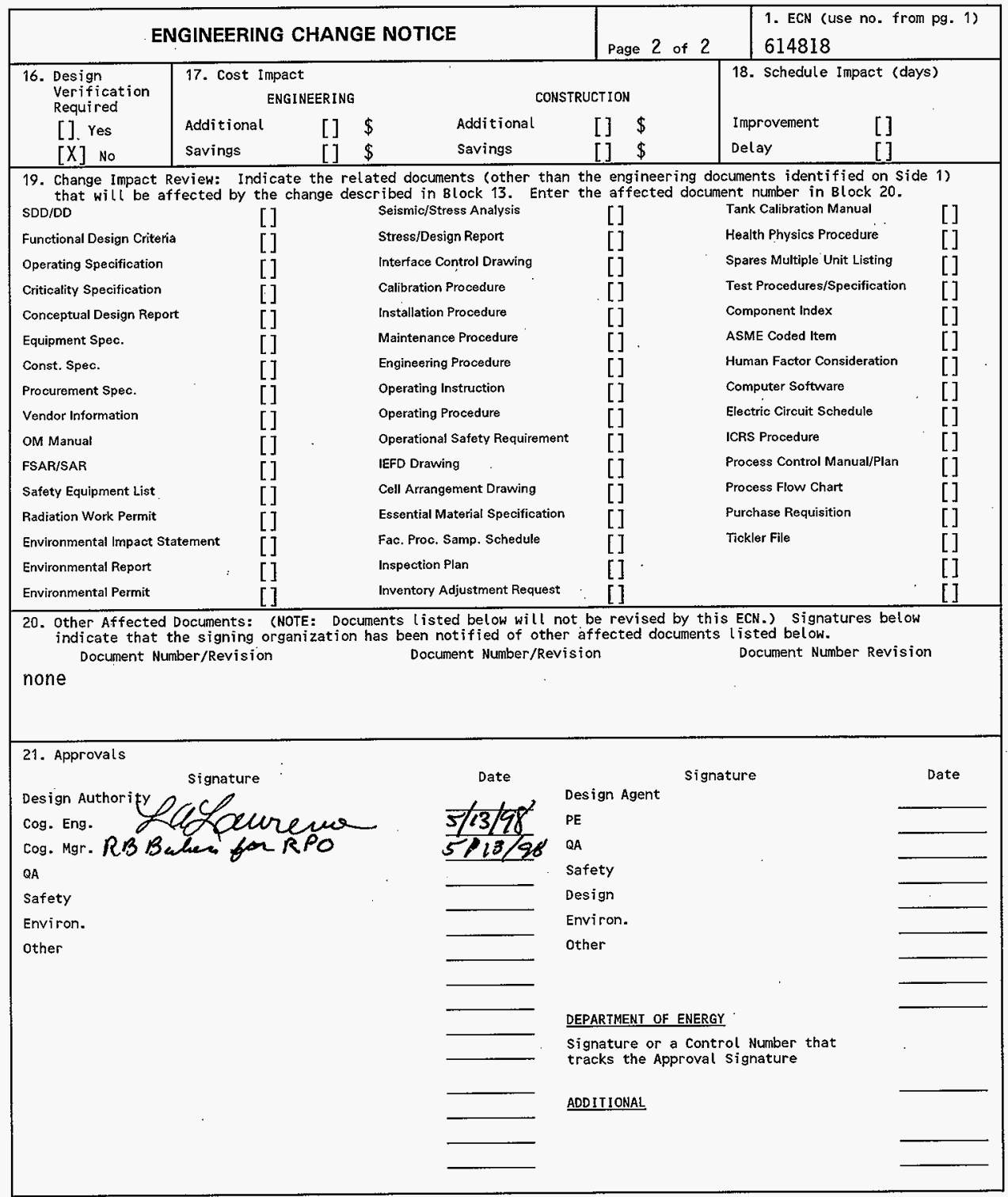




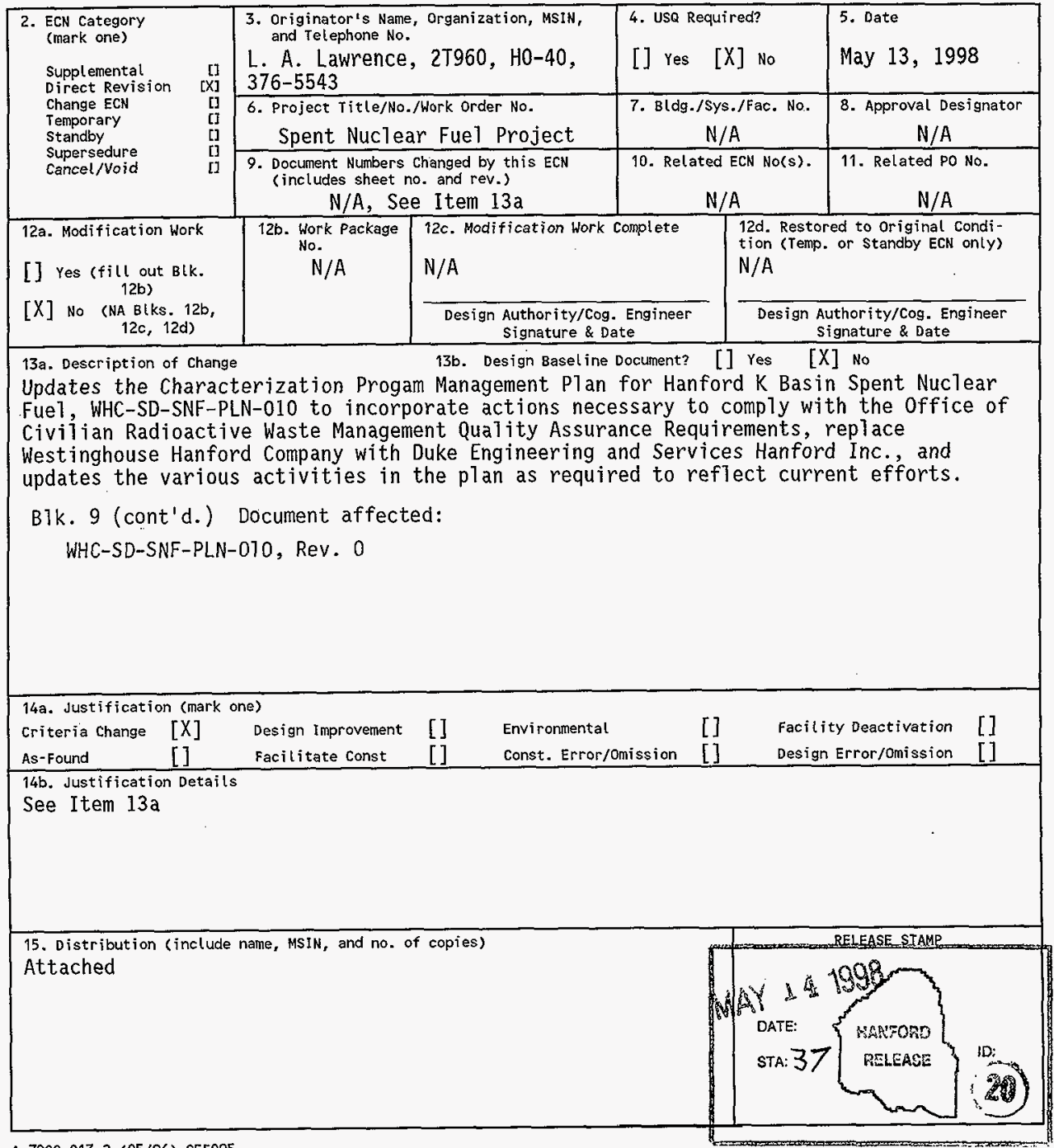




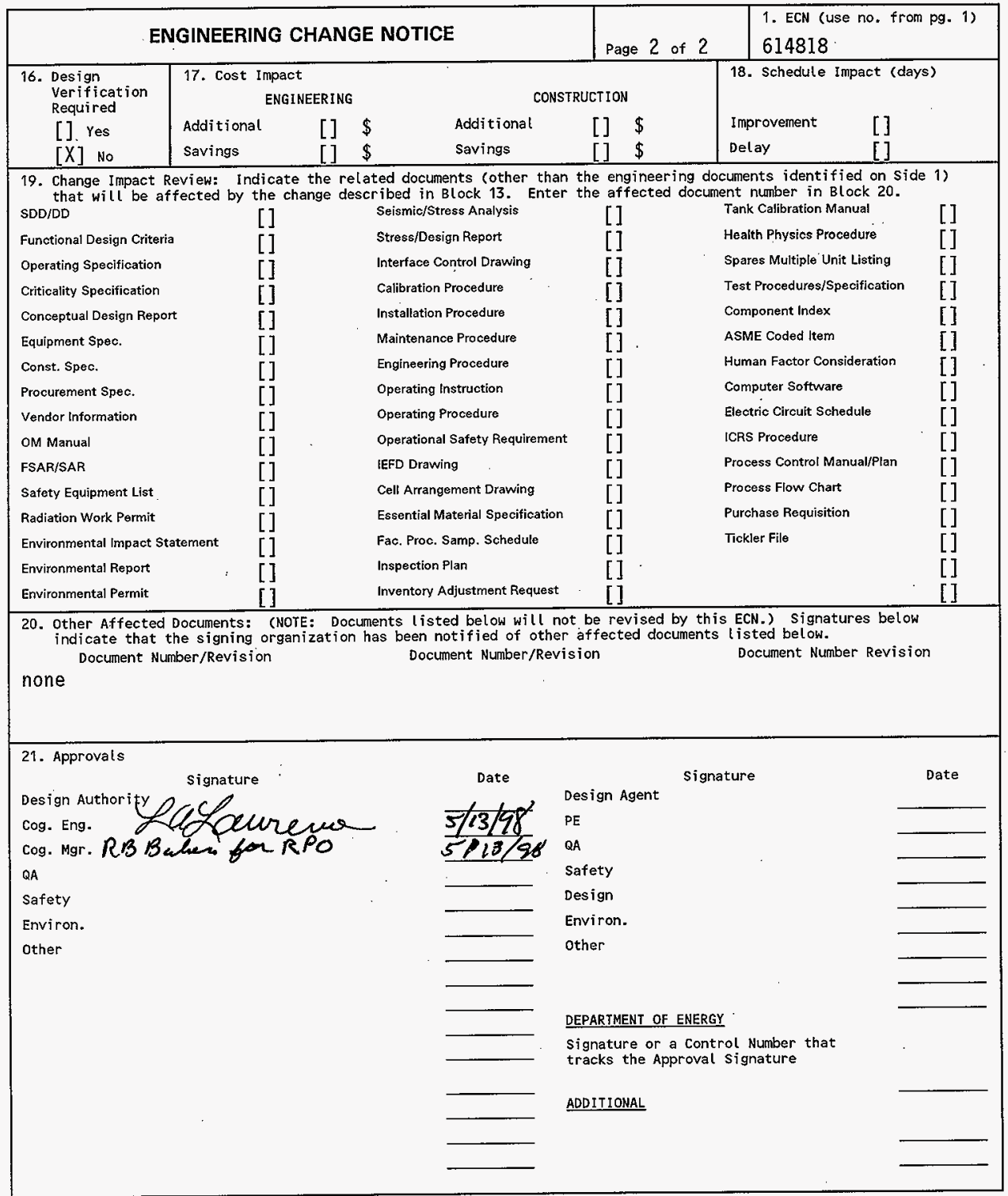


$H N F-W \mathscr{C} C-S D-S N F-P L N-010$, Rev. 1

\section{CHARACTERIZATION PROGRAM MANAGEMENT PLAN FOR HANFORD K BASIN SPENT NUCLEAR FUEL}

L. A. Lawrence

Duke Engineering \& Services Hanford, Inc., Richland, WA 99352

U.S. Department of Energy Contract DE-AC05-96RL13200

$\begin{array}{lll}\text { EDT/ECN: } & 614818 & \text { UC: } 2070 \\ \text { Org Code: } & 27960 & \text { Charge Code: } \\ \text { B\&R Code: } & \text { EW7040000 } & \text { Total Pages: } 48 \mathrm{ga}\end{array}$

Key Words: Spent Nuclear Fuel Project, Management P1an, Fuel Examinations, STudge Examinations, K Basins, Quality Assurance

Abstract: The management plan developed to characterize the $\mathrm{K}$ Basin Spent Nuclear Fuel was revised to incorporate actions necessary to comply with the Office of Civilian Radioactive Waste Management Quality Assurance Requirements Document 0333P. This revision to the Program Management Plan replaces Westinghouse Hanford Company with Duke Engineering \& Services Hanford, Inc., updates the various activities where necessary, and expands the Quality Assurance requirements to meet the applicable requirements document.

TRADEMARK DISCLAIMER. Reference herein to any specific commercial product, process, or service by trade name, trademark, manufacturer, or otherwise, does not necessarily constitute or imply its endorsement, recommendation, or favoring by the United States Government or any agency thereof or its contractors or subcontractors.

Printed in the United States of America. To obtain copies of this document, contact: Document Control Services, P.0. Box 950, Mailstop H6-08, Richland WA 99352, Phone (509) 372-2420; Fax (509) 376-4989.
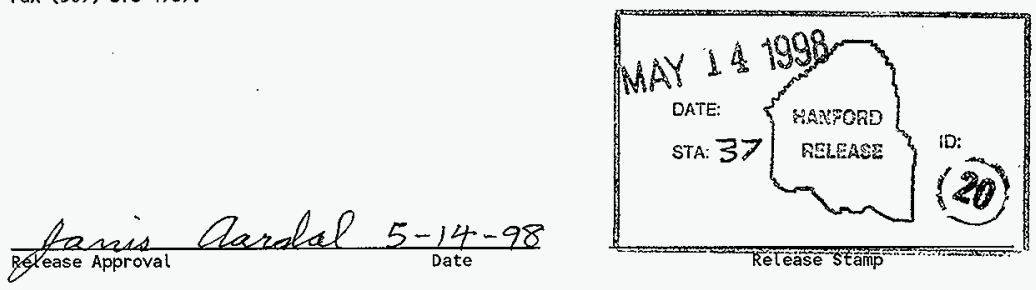
RECORD OF REVISION

(1) Document Number

WHTC-SD-SNF-PLN-010, Page 1 HNF ja ReV. 1

(2) Title

Characterization Program Management Plan for Hanford K Basin Spent Nuclear Fue] CHANGE CONTROL RECORD

\begin{tabular}{|c|c|c|c|c|}
\hline \multirow{2}{*}{ (3) } & \multirow{2}{*}{ Revision } & \multirow{2}{*}{ (4) Description of Change - Replace, Add, and Delete Pages } & \multicolumn{2}{|c|}{ Authorized for Release } \\
\hline & & & (5) Cog. Engr. & (6) Cog. Mgr. Date \\
\hline & 0 & (7) EDT-610184 October 18, 1995 & L. A. Lawrence & R. P. Omberg \\
\hline & 1 RS & $\begin{array}{l}\text { Plan revised to incorporate actions to } \\
\text { comply with OCRWM QARD, replace WHC with } \\
\text { DESH, and update the various activities. }\end{array}$ & $\begin{array}{l}\text { L. A. Lawrence } \\
\text { ofyenewee }\end{array}$ & $\begin{array}{l}\text { R. P. Omberg } \\
\text { PSBehenter RB }\end{array}$ \\
\hline & & Per ECN-614818. & $5-13-98$ & $8 / 13 / 98$ \\
\hline & & & & \\
\hline & & & & \\
\hline & & & & \\
\hline & & & & \\
\hline & & & & \\
\hline & & & & . \\
\hline & & & & \\
\hline & & & & \\
\hline & & . & & \\
\hline & & & & \\
\hline & & & & \\
\hline & & . & & \\
\hline & & & & \\
\hline & & & & \\
\hline & & & & \\
\hline & & & & \\
\hline & & & & \\
\hline & & & & \\
\hline & & & & \\
\hline & & & & \\
\hline & & & & , \\
\hline & & & & \\
\hline & & & & \\
\hline & & & & \\
\hline & & & & \\
\hline & & & & \\
\hline & & & & \\
\hline & & & & \\
\hline & & & & \\
\hline
\end{tabular}


g* Wh'C-SD-SNF-PLN-010, Rev. 1

May 1998

Duke Engineering \& Services Hanford, Inc. 
Document Title: CHARACTERIZATION PROGRAM MANAGEMENT PLAN FOR HANFORD

\section{K BASIN SPENT NUCLEAR FUEL}

Prepared by:
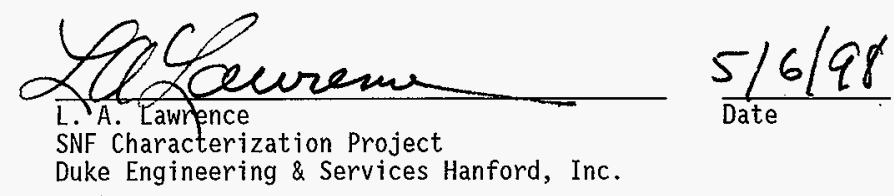

SNF Characterization Project

Duke Engineering \& Services Hanford, Inc.

Reviewed by:

M. J. Forhota

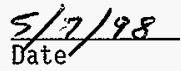

Quality Assurance

Duke Engineering \& Services Hanford, Inc.

Approved by:

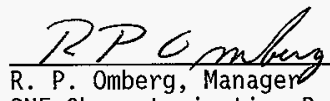

SNF Characterization Project

Duke Engineering \& Services Hanford, Inc.

Approved by:

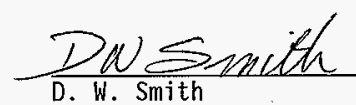

QuaTity Assurance

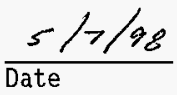

Duke Engineering \& Services Hanford, Inc.

Approved by:
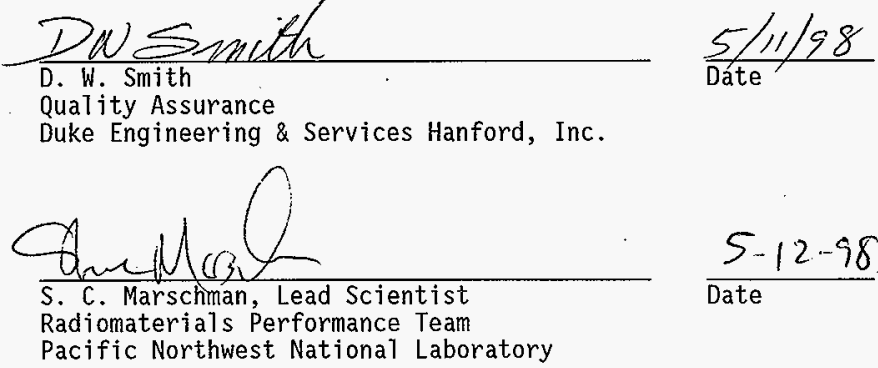

$$
\frac{5-12-98}{\text { Date }}
$$


HAF- WHC-SD-SNF-PLN-010, Rev. I

ya

\section{EXECUTIVE SUMMARY}

The management $\mathrm{plan}$ developed to characterize the $\mathrm{K}$ Basin Spent Nuclear Fuel was revised to incorporate actions necessary to comply with the Office of Civilian Radioactive Waste Management Quality Assurance Requirements Document 0333P. This $\mathrm{plan}$ was originally developed for Westinghouse Hanford Company and Pacific Northwest National Laboratory to work together on a program to provide characterization data to support removal, conditioning, and subsequent dry storage of the spent nuclear fuels stored at the Hanford K Basins. This revision to the Program Management Plan replaces Westinghouse Hanford Company with Duke Engineering \& Services Hanford, Inc., updates the various activities where necessary, and expands the Quality Assurance requirements to meet the applicable requirements document. Characterization will continue to utilize the expertise and capabilities of both organizations to support the Spent Nuclear Fuels Project goals and objectives. This Management Plan defines the structure and establishes the roles for the participants providing the framework for Duke Engineering \& Services Hanford, Inc. and Pacific Northwest National Laboratory to support the Spent Nuclear Fuels Project at Hanford. 
$H N F-\frac{W H C-S D-S N F-P L N-010,}{H a}$ Rev. 1

CONTENTS

1.0 INTRODUCTION . . . . . . . . . . . . . . . 7

2.0 SCOPE, OBJECTIVES, AND PROGRAM RESPONSIBILITIES ........ 9

2.1 SCOPE . . . . . . . . . . . . . . . 9

2.2 OBJECTIVES . . . . . . . . . . . . . . . . 9

2.3 PROGRAM RESPONSIBILITIES . . . . . . . . . . . 9

3.0 PROGRAM MANAGEMENT AND ORGANIZATION ............ 11

4.0 WORK BREAKDOWN STRUCTURE ................ 13

5.0 PROGRAM ELEMENT AREAS OF RESPONSIBILITY . . . . . . . . . 15

5.1 PLAN . . . . . . . . . . . . . . 15

5.2 IN-SITU K BASIN CHARACTERIZATION ........... 15

5.3 TRANSPORTATION ....................... 15

5.4 HOT CELL UPGRADES . . . . . . . . . . . . . . . . 15

5.5 QUALITY ASSURANCE . . . . . . . . . . . . 15

5.5.1 Spent Nuclear Fuel and Characterization Project
Quality Assurance Organization ..... 16

5.5.2 Office of Civilian Radioactive Waste Management
Quality Assurance Program . . . . . . . 20 20

5.5.3 Quality Assurance Controls ............. 21

5.5.4 Scientific Investigations ............ 23

5.6 HOT CELL EXAMINATIONS . . . . . . . . . . . . . . 29

5.7 WASTE MANAGEMENT . . . . . . . . . . . . . . . 29

5.8 DATA MANAGEMENT . . . . . . . . . . . . . . . . . . . . 29

5.9 DATA INTERPRETATION . . . . . . . . . . . . . 31

5.10 NATIONAL SPENT NUCLEAR FUEL PROGRAM ........... 31

6.0 PROGRAM INTERFACES AND COMMUNICATIONS ........... 33

6.1 MANAGEMENT POINTS OF CONTACT $\ldots 33$

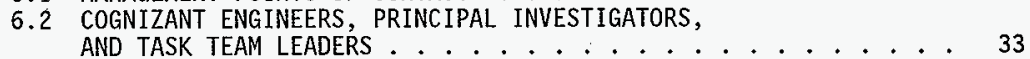

6.3 INTERFACE WITH SNF PROJECTS ............. 33

6.4 INTERFACES WITH OTHER HANFORD PROJECTS ......... 33

7.0 MEETINGS . . . . . . . . . . . . . . . . . 35

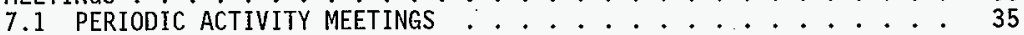

7.2 TECHNICAL REVIEWS . . . . . . . . . . . . . . 35

8.0 REPORTS AND DOCUMENTATION . . . . . . . . . . . . 37

8.1 TOPICAL REPORTS AND OPEN LITERATURE PUBLICATIONS . . . . . . . 37

8.2 PLAN, REQUIREMENTS, ROUTINE CORRESPONDENCE ........ 37

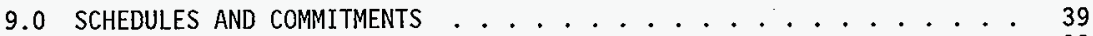

9.1 OVERALL PROJECT SCHEDULES . . . . . . . . . . 39

9.2 CHARACTERIZATION PROGRAM SCHEDULE AND MILESTONES ...... 39 
HNF-WHC-SD-SNF-PLN-010, Rev. 1

CONTENTS (Continued)

10.0 FUNDING ................................. 41

11.0 PROGRAM MANAGEMENT PLAN REVISIONS . . . . . . . . . . . 43

12.0 REFERENCES .................... . . . 45 


$$
\begin{aligned}
& \text { HNF-WHKC-SD-SNF-PLN-010, Rev. } 1 \\
& \text { Ha. }
\end{aligned}
$$

\section{LIST OF FIGURES}

1. SNF Characterization Project Organization Structure

for Achieving Quality .................... 17

2. SNF Characterization Project Organization Structure . . . . . . 19

\section{LIST OF TABLES}

1. SNF Characterization Project Responsibilities . . . . . . . . 18

2. Duke Engineering \& Services Hanford, Inc. Reports to Be Qualified . . . . . . . . . . . . . . . . . . 29

3. Pacific Northwest National Laboratory Characterization Reports to be Qualified. . . . . . . . . . . . . . 30 


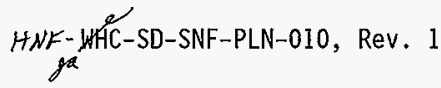

This page intentionally left blank. 


\section{HNF-YKC-SD-SNF-PLN-010, Rev. 1 \\ ga \\ CHARACTERIZATION PROGRAM MANAGEMENT PLAN FOR HANFORD K BASIN SPENT NUCLEAR FUEL}

\subsection{INTRODUCTION}

Duke Engineering \& Services Hanford, Inc. (DESH) has responsibility for management of the characterization program, including cost and schedule, and disposition of technical information to the project. Pacific Northwest National Laboratory (PNNL) has responsibility for managing the technical work at the laboratories needed to support the objectives identified by DESH, and responsibility to serve as a technical advisor to DESH. Characterization work supports resolution of the Hanford Spent Nuclear FueT (SNF) Project Path Forward storage issues.

N Reactor fuel has been stored for extended perjods of time in the Hanford $K$ Basins. This fuel is degrading with continued storage resulting in release of material to the basin water in $\mathrm{K}$ East Basin and to the closed storage canisters in $\mathrm{K}$ West Basin. Information on the condition of the fuel will support decisions for the removal, transport, conditioning, storage, and ultimate future disposal of the materials in both the open and closed storage canisters. The fuel must be placed in a safe interim storage condition for an extended period before ultimate disposal in a waste repository.

The characterization activity for the Hanford SNF will address the identified issues related to the condition of the fuel, which are continued degradation, fuel conditioning, and interim storage for an extended period of time.

The characterization activities are structured to support design decisions for the path to interim storage, the Environmental Impact Statement (EIS) and corresponding Record of Decision (ROD), and the safety analysis reports. However, due to the aggressive schedule of the SNF program, the design, EIS preparation and safety analys is functions are proceeding in parallel with characterization. Consequently, characterization data will also confirm key decisions and assumptions while providing bases for subsequent process refinements.

This revision to the Program Management Plan (PMP) updates the various activities and expands the Quality Assurance (QA) requirements to comply with the Office of Civilian Radioactive Waste Management (QCRWM) Quality Assurance Requirements Document (QARD) 0333P. The corrective actions necessary to implement this QARD for the characterization Project at DESH were identified in the QA Implementation P1an (Horhota 1997). The appropriate actions in this Implementation Plan are incorporated into this revision to the PMP.

The PNNL QA plan is in full compliance with the QARD as evidenced by the most recent audit of the PNNL Characterization Program (Lawrence 1997). Therefore, this revision to the PMP does not address any changes or revisions to the PNNL program. 
HNF. WHC-SD-SNF-PLN-010, Rev. 1

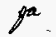

This page intentionally left blank. 
$H N F-$ WHCL-SD-SNF-PLN-010, Rev. 1

\subsection{SCOPE, OBJECTIVES, AND PROGRAM RESPONSIBILITIES}

\subsection{SCOPE}

The scope of this PMP focuses on the $N$ Reactor fuel stored in the Hanford $K$ Basins and corresponding sludge and any Single Pass Reactor (SPR) fuel remaining in storage.

Characterization activities will be planned to obtain key information needed to support Path Forward decisions, in the shortest period of time. Detailed characterization plans will be structured using the Data Quality Objective (DQO) process to support Path Forward project decisions (Lawrence 1994).

\subsection{OBJECTIVES}

The following objectives were established for the SNF Path Forward project characterization activities:

1. Provide a guiding methodology for identification, collection, and reporting characterization data.

2. Support Multi-Canister Overpack (MCO) design decisions for transport and interim dry storage within regulatory compliance.

3. Develop a data base to support fuel processing for transition from current configurations to interim dry storage.

4. Support development of the safety envelope for fuel retrieval, MCO loading, cold vacuum drying, and transportation and storage in the container storage bujlding.

5. Support issuance of the EIS/ROD.

6. Provide data to support interim storage and monitoring.

\subsection{PROGRAM RESPONSIBILITIES}

The SNF Characterization Project group is responsible for the characterization of the fuel and sludge in the $K$ East and $K$ West storage basins. Characterization activities include both the in-situ measurements and extended laboratory examinations. The SNF Characterization Project group is responsible for all aspects associated with program development, sample selection, sample retrieval, in-situ and laboratory measurements, data analysis, and reporting. The SNF Characterization Project group utilizes the needed expertise in the other Hanford site contractors to support the various activities associated with the overall characterization efforts. 
HNF-HHC-SD-SNF-PLN-010, Rev. 1

pa

This page intentionally left blank. 
$H N F-14 K C$ CSD-SNF-PLN-010, Rev. 1

\subsection{PROGRAM MANAGEMENT AND ORGANIZATION}

Duke Engineering \& Services Hanford, Inc. has responsibility for defining the envelope of requirements for characterization to support the SNF project, for conducting in-situ characterization in the basins, for preparation and shipments of materials to the hot cells for examinations, for requests for information from the hot cel] examinations, and for interpretation of the results for the SNF Project. DESH is also responsible for supplying characterization information to support other project objectives.

Pacific Northwest National Laboratory has joint responsibjlity for planning and technical direction of the hot cell fuel and sludge examinations. Pacific Northwest National Laboratory is responsible for preparation and operation of PNNL facilities to carry out examination work, and for evaluation of data gained from characterization activities for technical significance and quality. PNNL will also provide expert technical advice to DESH on characterization matters. 
HNF- Ja $^{\circ}$ CC-SD-SNF-PLN-010, Rev. I

This page intentionally left blank. 
HNF- $W H C$ C SD-SNF-PLN-010, Rev. I

\subsection{WORK BREAKDOWN STRUCTURE}

The Work Breakdown Structure (WBS) for the characterization program will be fully integrated and consistent with the WBS for the SNF Project. Characterization will use the WBS developed by the SNF Project for the Multi-Year Program PIan (MYPP). The WBS can be obtained from the current MYPP. 
HNF- $y=\mathscr{C} C-S D-S N F-P L N-010$, Rev, 1

This page intentionally left blank. 


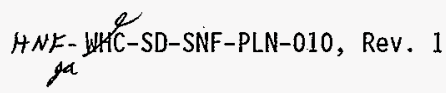

\subsection{PROGRAM ELEMENT AREAS OF RESPONSIBILITY}

\subsection{PLAN FOR CHARACTERIZATION OF $K$ BASIN SPENT NUCLEAR FUEL AND SLUDGE}

The Plan for Characterization of $\mathrm{K}$ Basin SNF and sludge outlines the data needed to support the SNF and sludge Path Forward decisions (Lawrence 1995). DESH has the responsibility for preparation and maintenance of the Plan, and for any revisions that are prepared as work progresses and data are obtained with corresponding increases in understanding of the material characteristics and conditions in the $\mathrm{K}$ Basin. The planning process is a team effort between DESH, Fluor Daniel Hanford Company (FDH), and PNNL.

\subsection{IN-SITU K BASIN CHARACTERIZATION}

The characterization activities at $K$ Basin include a detailed review of historical records to establish parameters for the materials stored in the K Basins, in-situ examinations of the materials stored in the Basins, development of a data base on the initial conditions of the fuel canisters, and sludge, in both $\mathrm{K}$ Basins, and evaluations of the data collected during the in-situ examinations. DESH has responsibility for characterization activities at $K$ Basin recognizing DESHs primary responsibility for the $K$ Basins operations and surveillance activities. PNNL will provide expert advice for $\mathrm{K}$ Basin characterization activities.

\subsection{TRANSPORTATION}

Materials will be transported between the K Basin and the various on-site laboratories and hot cells for examinations as part of characterization. DESH will have the primary responsibility for all aspects of the movement of materials from one location to another. Once material has been transported to a PNNL facility, it will become the responsibility of PNNL until it is returned to DESH. PNNL will be responsible for a 11 material movements within and between their facilities and for sending test residuals to Central Waste. DESH will have primary responsibility for preparation of the return shipment of SNF sample remains to $K$ Basins.

\subsection{HOT CELL UPGRADES}

Selected hot cell upgrades will be necessary to implement characterization. PNNL will be responsible for these upgrades recognizing PNNLs primary responsibility for operation of these facilities. PNNL will manage the upgrades to be fully responsive to the SNF Project requirements and schedules for characterization.

\subsection{QUALITY ASSURANCE}

The Quality Assurance (QA) for the characterization activities and data management will be in full compliance with the Office of Civilian Radioactive 


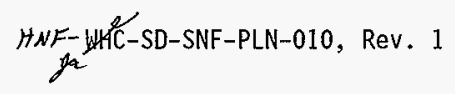

Waste Management (OCRWM) Quality Assurance Requirements and Description (QARD), RW-0333P; (SeTlers 1995). The characterization activities and data management will comply with the individual DESH and PNNL company $Q A$ requirements.

An implementation plan was prepared for characterization to comply with the QARD (Horhota 1997). The compliance plan identified four areas as requiring additional program definition. The four areas are: organization, QA program, sample control, and scientific investigation. The Characterization Project QA requirements and definitions on these four areas are defined in the following sections.

SNF Characterization Project activities will be subject to independent oversight by the SNF QA and FDH QA organizations. For a list of surveillance and audit or assessments planned for the Characterization Project refer to the DESH surveillance and FDH independent program schedules.

SNF Characterization Project activities are structured to support design decisions for the interim storage of the fuel, the safety basis document, and fuel conditioning. The test data being collected will be used either directly or indirectly to confirm acceptable range of process conditions and/or design nuclear safety structures, systems and components that will either prevent or mitigate releases to the off-site public or on-site worker that would exceed radiological risk guidelines called out in HNF-PRO-704. Therefore, these data collection activities are considered quality affecting and must be planned and performed under a QA program that is based on the requirements defined in the Project Hanford Quality Assurance Program Description document (HNF-MP-599) and SNF Project Quality Assurance Program Plan (QAPP) (CM-5-13, Section 1.4).

In addition some of the data collection activities performed by the SNF Characterization Project will provide information that will either directly or indirectly impact processes or systems that will establish properties or behavioral characteristics for the final disposition of Hanford SNF in the geologic repository. Therefore, these activities will also have to comply with OCRWM QARD RW-0333P. See Section 5.6.2 for a list of those OCRWM related activities.

\subsubsection{Spent Nuclear Fuel and Characterization Project Quality Assurance Organization}

The SNF Project and Characterization Project organizational responsibilities for $Q A$ and the various tasks within the Characterization Project are defined in this section of the PMP. The overall organizational structure within the SNF Project for QA is summarized in Figure 1 . The structure includes both the technical and line management responsibilities for characterization and QA as well as the interface with PNNL and QA Engineering support. The QA organization is structured to provide independent oversight and QA support to. SNF Characterization Project quality objectives and satisfies the organizational responsibilities identified in the SNF Characterization Project QAPP (CM5-13, Section 1.4). 


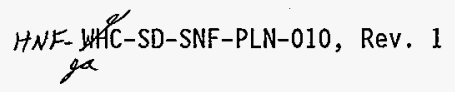

Figure 1. SNF Characterization Project Organization Structure for Achieving Quality.

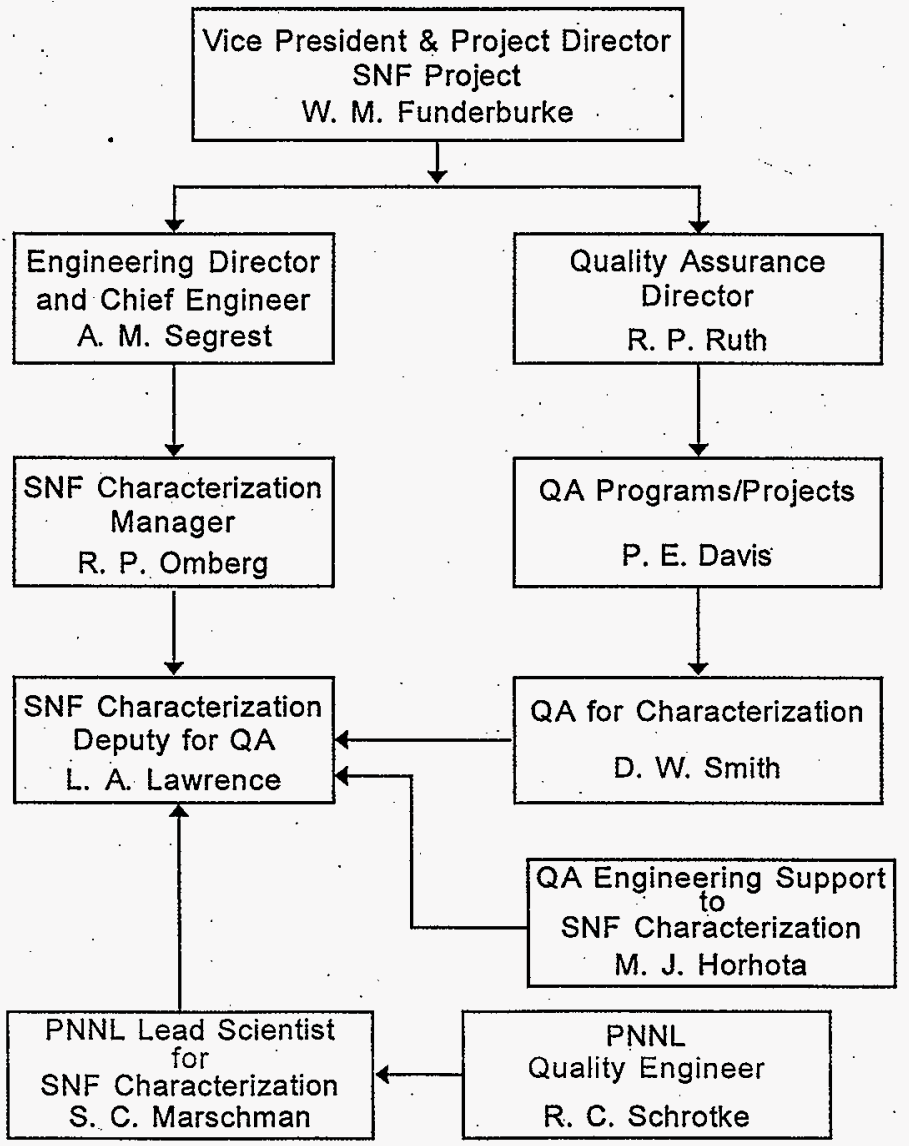


HNF-WHLC-SD-SNF-PLN-010, Rev. 1

The SNF Characterization Project manager, R. P. Omberg is responsible for:

- Overall program scope and schedule

- Multi-year program funding

- Work assignments within characterization

- Interfaces with other SNF Project organizations

- Overall responsibility for characterization data quality and support to the SNF Project.

R. P. Omberg has made several lead assignments within the SNF Characterization Project organization.

The SNF Characterization Project is divided into five lead areas of responsibility (Figure 2). The identified individuals are responsible for the specific areas of the Characterization Project. The individual areas of responsibility under the fuel, sludge, and in-situ examination are further defined in Table 1. In this responsibility matrix SNF Characterization Project staff members are identified for the specific areas necessary to complete the tasks under the three general characterization topics.

The organizational structures and responsibility matrices will be revised as the management structures are redefined and SNF Project individuals are assigned different areas of responsibility. This PMP will be revised as necessary where there are significant revisions to the organization structure and the individual areas of responsibility.

Table 1. SNF Characterization Project Responsibilities.

\begin{tabular}{|c|c|c|c|c|c|}
\hline \multirow[b]{2}{*}{$\begin{array}{c}\text { Areas of } \\
\text { Responsibility }\end{array}$} & \multirow[b]{2}{*}{ Fuel } & \multirow[b]{2}{*}{ Sludge } & \multicolumn{3}{|c|}{ In-Situ Examinations } \\
\hline & & & Fuel & Sludge & $\begin{array}{c}\text { Closed } \\
\text { Canisters }\end{array}$ \\
\hline Programmatic & L.A. Lawrence & R.B: Baker & L.A. Lawrence & R.B. Baker & D.J. Trimble \\
\hline $\begin{array}{l}\text { Interface with } \\
\text { laboratories }\end{array}$ & $\begin{array}{l}\text { L.A. Lawrence/ } \\
\text { S.A. Chastain }\end{array}$ & $\begin{array}{l}\text { R.B. Baker/ } \\
\text { S.A. Chastain }\end{array}$ & $N / A$ & $N / A$ & D.J. Trimble \\
\hline $\begin{array}{l}\text { Equipment } \\
\text { development }\end{array}$ & L.A. Lawrence & A.E. Bridges & A.L. Pitner & A.E. Bridges & $\begin{array}{l}\text { D.J. Trimble/ } \\
\text { A.E. Bridges }\end{array}$ \\
\hline Sample collection & J.J. Jernberg & J.J. Jernberg & A.L. Pitner & J.J. Jernberg & J.J. Jernberg \\
\hline Data collection & L.A. Lawrence & R.B. Baker & A.L. Pitner & R.B. Baker & D.3. Trimble \\
\hline Data analysis & B.J. Makenas & B.J. Makenas & A.L. Pitner & B.J. Makenas & D.J. Trimble \\
\hline Data reporting & L.A. Lawrence & B.J. Makenas & A.L. Pitner & R.B. Baker & D.J. Trimble \\
\hline Data storage & $\begin{array}{l}\text { L.A. Lawrence/ } \\
\text { L.D. Bruggeman }\end{array}$ & $\begin{array}{l}\text { R.B. Baker/ } \\
\text { L.D. Bruggeman }\end{array}$ & A.L. Pitner & $\begin{array}{l}\text { R.B. Baker/ } \\
\text { L.D. Bruggeman }\end{array}$ & $\begin{array}{ll}\text { D.J. } & \text { Trimble/ } \\
\text { L.D. Bruggeman }\end{array}$ \\
\hline
\end{tabular}




\section{$H N F-$ PHTC-SD-SNF-PLN-010, Rev. 1}

Figure 2. SNF Characterization Project Organization Structure.

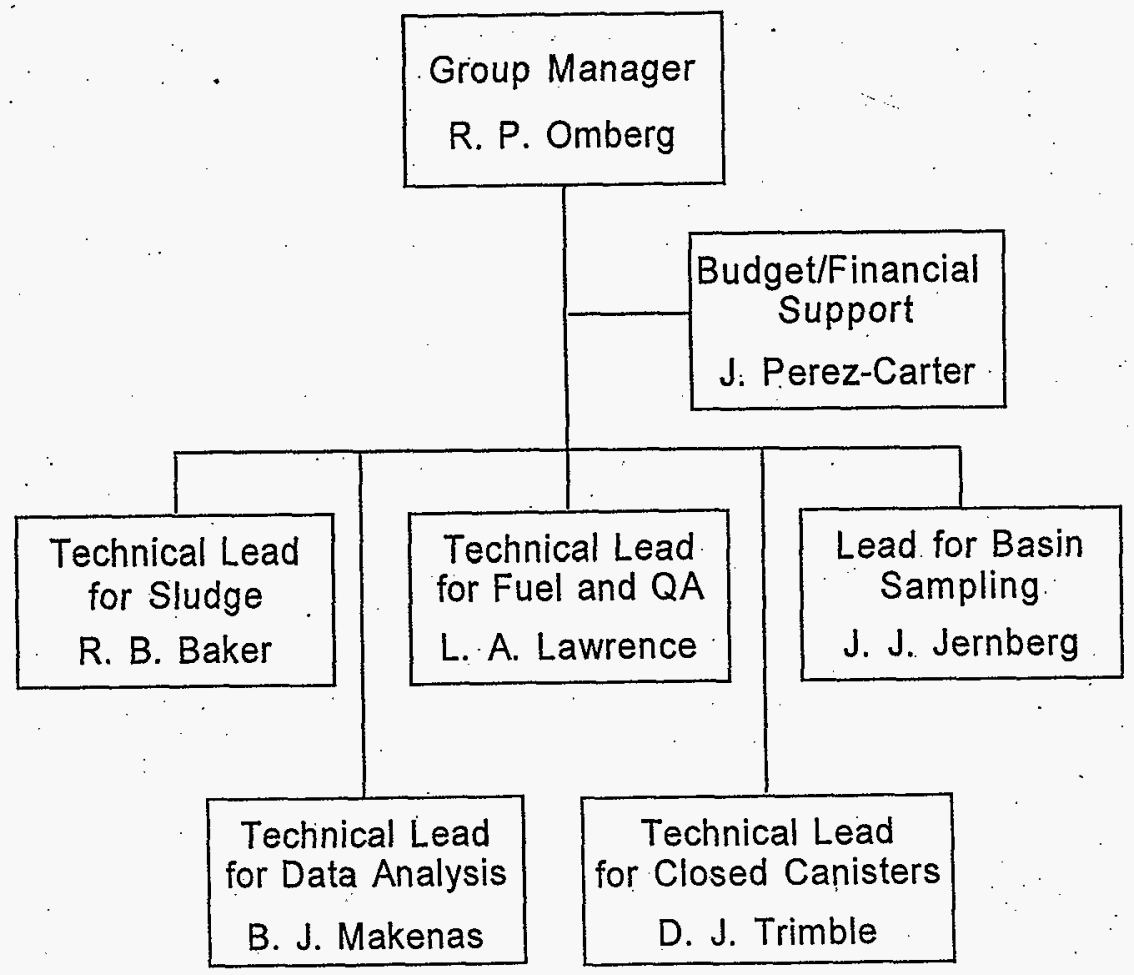




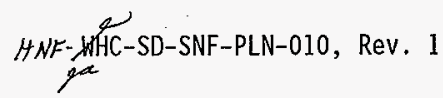

\subsubsection{Office of Civilian Radioactive Waste Management Quality Assurance Program}

The activities within the Characterization Project were identified that fall within the scope of the OCRWM QARD (McCormack 1997). Fundamentally data generated concerning any fuel or related materials that are expected to be loaded into the MCOS falls within the scope of the QARD. The following specific activities were identified:

- In-situ fuei video examinations to cover fuel surface area and amount of particulate matter

- Metallographic examinations of fuel samples

- Small sample furnace fuel drying and ignition testing

- Whole fuel element drying studies

- Fuel subsurface sludge and surface coating examinations

- Thermo-Gravimetric Analysis (TGA) for fuel oxidation and fuel, sludge, and coating drying studies.

In addition to these experimental activities the following analytical efforts were identified

- Fuel surface area analysis

- Validation of reaction rates of exposed surfaces in an MCO.

The application of the QARD to each of these experimental activities will be defined in the following sections of this PMP. The noted analytical efforts will be covered by the overall SNF Project QA requirements in this area.

5.5.2.1 In-Situ Fuel Video Examinations. The extent of fuel degradation was recorded on video tape during a nearly complete survey of the K East Basin and from examinations of selected closed canisters in the $K$ West Basin. Fuel surface area estimates are based on the results of the video surveys. A statistically based sampling plan was prepared for the closed canister examinations and the full Tength examinations in the K East Basin. Detailed project reports were prepared for each sampling campaign. These reports tabulate the results of the video surveys. The tabulated data and the corresponding project reports are considered to be permanent records and protected as such. The video tapes created during the examinations are not considered to be a permanent record and will not be controlled and safe guarded as permanent record. This information is used as a basis for process development and the safety basis.

The data generated during the in-situ video examinations will be qualified to the OCRWM QARD using an Independent Technical Review (see Section 5.5.4.2.1).

5.5.2.2 Metallographic Examinations. The metallographic examination of small fuel samples was conducted by PNNL with DESH concurrence on sample selection and examination objectives and techniques. The final report of these examinations was completed and has been qualified by the Independent Technical Review. 


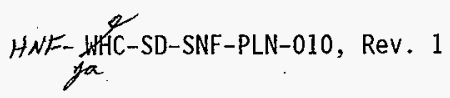

The $Q A$ requirements for these examinations were defined by PNNL within their OCRWM approved QA Plan.

5.5.2.3 Small Sample Furnace Testing. The furnace testing of small fuel samples for drying and ignition temperatures were conducted by PNNL under their OCRWM approved QA P1an. These requirements were documented in the appropriate PNNL test $\mathrm{plans}$ and test instructions which were approved by DESH.

One report covering the ignition testing has been completed and is now undergoing an Independent Technical Review (ITR) for qualification to the QARD (see Section 5.5.4.2.2).

5.5.2.4 Whole Element Drying Testing. The strategy for whole element furnace testing damaged $K$ West and $K$ East fuel was established by DESH with PNNL approvat (Lawrence 1998, 1997b, 1996). PNNL conducted these tests under their OCRWM approval QA Plan. PNNL prepared detailed Test Plans and Procedures for DESH formal approval for each furnace run.

A complete series of reports covering the furnace testing are being prepared by PNNL and are being qualified with an ITR under their OCRWM approved QA PTan (see Section 5.5.4.2.2).

5.5.2.5 Fue1 Subsurface Sludge and Surface Coating Examinations. Damaged $K$ East and $K$ West.fue? elements were selected by DESH for recovery of subsurface sludge and surface coatings for characterization. DESH directed the sample recovery in the Hanford hot cells. The PNNL analytical

laboratories conducted the necessary examinations of the materials collected. Direction to PNNL was provided by Letter of Instruction and the work performed under the PNNL QA Project Plan for the K Basin Fuel Element Subsurface Sludge Examinations Project Number 28964 dated November 14, 1997. This QA PI an was approved by DESH as meeting the QARD. A final QA reviewed 1aboratory data report will be provided to DESH. DESH will prepared a summary report of the data for SNF Project use. This report will be qualifjed with an ITR (see Section 5.5.4.2.1).

5.5.2.6 Thermo-Gravimetric Analysis. Small samples removed from the damaged fuel elements will be measured for reaction rates, and drying behavior in the TGA by PNNL. The testing is defined by DESH using Examination Strategy documents and letters of Instruction. PNNL prepares a Tests Plan and appropriate Test Instruction for each test run or series of runs in accordance with the PNNL approved QA PTan. Detailed reports of the measurements are prepared by PNNL for ITR. Test plans, test instructions, and final reports are approved by DESH.

\subsubsection{Qual ity Assurance Controls}

The specific $Q A / Q C$ controls that will be used to collect and analyze the data obtained from the SNF and sludge sample defined here are based on practices recognized by the U.S. EPA for environmental sampling. It is recognized that a number of other management systems necessary to implement the K Basin SNFP QA program (e.g., Training/Qualification, Quality Improvement, Document/Records, procurement, Management and Independent 


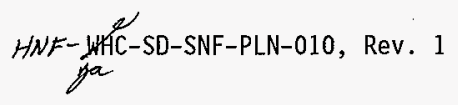

Assessments) are required to support this activity. However, because they are common to a11 SNFP quality affecting functions they will not be specifically repeated here.

\subsubsection{Data Quality Objective Development. The DQO process is the} scientific method used by the SNF Characterization Project group to outline the data collection strategy. The DQO process is based on the Environmental Protection Agency's guidance document QA/G-4 (EPA 1993). The DQO supports the sample collection design that will produce data of sufficient type, quantity, and quality to satisfy the data users needs and support technically defensible decision making.

A11 SNF Characterization Project sampling campaigns will be planned using the modified DQO process called out in SNF Project Characterization Data Quality Objectives Strategy (Lawrence 1994). The results of the DQ0 process will be documented, issued, and controlled as an Engineering Support Document in accordance with requirements in HNF-PRO-439.

In its simplest form, the $\mathrm{DQO}$. Process asks the program participants to address three key questions: What data are required to answer the question(s) posed, what new data are required, and how will the newly obtained data be used to answer the question(s) posed? The SNF Project is fully committed to utilizing the DQO approach to define characterization needs (Lawrence 1994). The DQO process will govern the development of the individual test plans and instructions prepared for each logically identified series or group of examinations or measurements.

5.5.3.2 Sample Control. The requirements for SNF Characterization Project sample control are established in procedure HNF-PR0-1884. This procedure implements the necessary sample controls to assure compliance with the OCRWM $Q A R D$. This procedure is used for collection of samples at the $K$ Basins and for sample control during laboratory testing and analysis.

Samples that do not meet the requirements specified in work controlling documents (e.g., JCS work packages, procedures, sample analysis plans, etc.) would be considered nonconforming and shall be documented and dispositioned using the NCR process identified in HNF-PR0-298.

Samples are considered nonconforming when the quality or integrity of the sample can no longer be assured.

Examples of nonconformance are: Chain of custody is missing, sampling instructions were not followed, sample traceability is lost, and sample identification numbers were duplicated.

5.5.3.3 Quality Control Samples. In order to monitor the overall performance of the analytical measurement system, Quality Control (QC) samples will be taken in either the field or the laboratory or both. The following types of QC samples are recommended for introduction into fuel and sludge data collection process when possible. The cognizant engineer will determine what 
HNF- Wa KC-SD-SNF-PLN-010, Rev. 1

types of QC samples are appropriate for each sampling campaign and identify then in the sampling documents or procedures. The following are recommended frequencies:

- Duplicate Samples: At least $25 \%$ of the samples will be collected in duplicate.

- Equipment BTank: Each day of sampling.

- Trip Blank: One trip blank will be included with each shipping container.

- Spike Sample: At least $10 \%$ of the sludge samples will be spiked by the laboratory.

5.5.3.4 Data Review and Validation. Each analytical data package that is prepared by the laboratory will be internally reviewed by the laboratory to assure the following:

- SNF Characterization Project requirements, stated procedures, and protocols were correctly followed.

- Required QC check samples, method control (calibration) standards, etc., have been performed and the results are within specified limits.

- Analytical results are correct and accurate.

- Analytical variability (e.g., precision, accuracy, etc.) are within specified tolerances.

- Any data anomalies have been addressed.

SNF Characterization Project will independently review each analytical data package for data validation to assure the project objectives (DQOs) have been satisfied and the data is suitable for its intended use. SNF Characterization Project will document this review as part of the final test report that will be issued and controlled as an Engineering Supporting Document per the requirements in HNF-PRO-439.

\subsubsection{Scientific Investigations}

The SNF Characterization activities fall within the QARD category of scientific investigations. ATl work will be controlled to the SNF Project Administrative Procedure, Control of OCRWM Scientific Investigation Work, AP6-015-00. Specific details of how the characterization work will be controlled and the preparation of final test reports are in the following sections of this PMP.

5.5.4.1 Control of Characterization Work. The necessary planning activities, methods to acquire the data, analysis of the data, and data reviews to conduct the scientific investigations are described in the following sections.

5.5.4.1.1 Planning Scientific Investigations. The responsible Cognizant Engineer will plan each SNF and sludge. sampiling campaign using the DQO process 


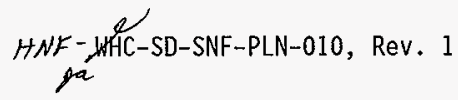

described in the Characterization Data Quality Objectives Strategy document (Lawrence 1994): Upon completion of the first six steps of the process the Cognizant Engineer should be able to define the following information:

- Who are the data users (stakeholders) and what their data needs are

- Who is (are) the individual(s) responsible for making the final decisions (key decision maker)

- List of the objectives or problems (decisions) that the sampling campaign must address

- Identify the problem resolution strategy for each of the listed objectives

- Define the technical information that must be collected or known in order for the objectives to be achieved

- Identify the logic (decision rule) that will be used to resolve the objectives with the information collected

- Identify the accuracy, precision, and representativeness (decision error) required of the results in order to make correct decisions.

The Cognizant Engineer will take the information obtained from the DQO process and following the formatting guidelines in WHC-EP-0795 prepare a DQO document that will be issued as a Project Document. Because of the wide spectrum of data needs, the SNF Characterization DQOS process is designed to be flexible and allows the degree of detail and depth to which the process is followed to vary with each sampling campaign. Depending upon the data needs and how well defined and mature the information available to support a decision are, the Cognizant Engineer may not be able to complete each step of the process. In those cases he or she will simply identify which steps of the DQO process are applicable or not.

The Cognizant Engineer wi11 complete the DQ0 process by formulating a sample collection scheme or strategy that will best satisfy the SNFP decisions and data needs. A Sampling and Analysis Plan (SAP) will be used for the sludge samples. An examination strategy or $\mathrm{plan}$ wijl be prepared for the fuel elements selected and the associate samples removed from these elements. These will be issued either as part of the DQO document or as a separate Project Document. Typically these documents will contain the following types of information:

- The number of samples to be taken

- The locations of where the samples will be taken (e.g., fuel element or canister number)

- The type, number, and frequency of Quality Control (QC) samples to be taken (e.g., duplicates, blanks, etc.)

- The sampling and analytical test procedures that will be used

- Any special instructions for handling, subdividing, or compositing the samples

- Any required fieid measurements that needs to be taken

- Any special instructions regarding sample preparation and analysis. 


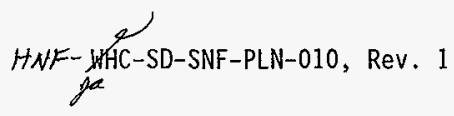

Because of the limited amount of fuel and sludge material avajlable for testing, at the discretion of SNF Characterization Project management, additional sample planning documents may be required to assure sufficient material is collected and is avajlable for testing on a case by case basis. These documents may include but are not limited to the following:

- Sample Strategy Document--These documents will be used to describe the approach to be used in selecting SNF samples for testing at the laboratory and supplements the information found in other planning documents such as the DQOS. These referenceable program letters and documents will include or reference sectioning diagrams that show how fuel elements will be subdivided, how they are labelled and to what tests they will be subjected to.

- Canister and or SNF Element Selection Document--These referenceable program letters or documents will be used to identify potentia] candidate canisters or SNF elements from which actual fuel or sludge samples can be taken. These documents will identify the selection criteria that will be used for choosing what canisters or fuel elements will be sampled.

5.5.4.1.2 Acquiring the Data. The Cognizant Engineer will be responsible for preparing either a work package in accordance with $K$ Basin Administrative Procedure 7-002 "100-K Area Work Control" or Technical Procedure in accordance with "K Basin Administrative Procedures 9-001-02" to control sample collection activities within the Basin. Depending upon the complexity of the task, additional work control documents (e.g., test instructions, procedures, etc.) may be required to provide the test operators and test engineers with sufficient instructions for performing the sampling.

Sampling personnel are responsible for physically identifying sample containers with the appropriate sample identification numbers as called out in the work package. In addition, sampling personnel will initiate a Chain of Custody and a Sample Analysis Request form from each of the samples collected in accordance with SNF Characterization Procedure HNF-PRO-1884. Independent verification by $Q A$ of sampling activities, labeling and sample documentation wi 11 be performed in accordance with the instruction provided in the Work Package or Technical Procedure.

Field measurement taken at the time of sampling will be traceable to the sample number. Data taken will be recorded on a Master Work Plan, the Technical Procedure, or on forms that are included as part of approved procedures.

5.5.4.1.3 Conducting the Analysis. Prior to collecting the sample, the Cognizant Engineer is responsible for establishing an analytical services contract with either an on-site or off-site laboratory for any physical or chemical testing required. Procurement documents or work agreement documents (e.g., Letter of Instruction, Statements of Work, etc.) will be prepared in 
accordance with the requirements found in Section 7.0 of HNF-MP-599 "Project Hanford Quality Assurance Program Description." These procurement documents shall address the following:

- The scope of the analytical testing required

- The analytes or physical characteristics of interest

- The anticipated number of samples, along with a sample collection schedule

- Matrices to be sample (e.g., sludge or fuel samples)

- The required analytical testing methods, including any necessary detection limits

- Any precision, accuracy, and completeness requirements to satisfy the DQOS

- Quality Assurance requirements, including required laboratory control samples

- Data reporting requirements and required documentation to be submitted for DESH review

- Data verification and data review requirements.

Testing that is performed by DESH will be conducted in accordance with approved test plans, instructions, or procedures per the requirements in HNF-PRO-446 "Test Practices Requirements." Test results will be documented in a test report prepared in accordance with HNF-PRO-446 or as directed in the work instructions.

The laboratory will prepare an analytical data package(s) to document the test results. These packages shall meet the requirements specified in the procurement documents or work agreement documents covering the laboratory's work scope and must contain the following information:

- Analytical results traceable to the SNF Characterization Project sample identification numbers. If unique laboratory identification numbers are used a cross reference to the project's sample information must also be included

- The resuits of all required analysis including duplicate results

- The results of all QC data (e.g., spike recovery results, Taboratory control standard results, trip, hot cell or equipment blank results, etc.)

- Deviations from established procedure or SNF instructions, along with the reason for the deviation

- Other data anomalies, outliners or deficiencies and their impact on the data

- Completed Chain of Custody forms 


$$
\text { HFN- WHC-SD-SNF-PLN-010, Rev. } 1
$$

- Narrative summarizing the analysis results and the quality of the results

- Signature and title of individual responsible for the content of the report.

Laboratory test data reports may also include a summary of all the test data in cases where significant quantities of data are generated as computer files such as for the whole element drying and TGA measurements. The base data wi11 be stored in a $Q A$ approved manner to reproduce the summary information provided in the test report.

5.5.4.1.4 Data Traceability. SNF Characterization Project data will be traceable back to the sample identification number. Through the sample ID number the documentation associated with the sample collection, analysis, and evaluation can be located. By reviewing this documentation the qualification status of the data will also be known.

SNF Characterization Project test reports or data validation reports will include data qualifiers that will indicate the qualification status of the data. The following qualifiers will be used:

- Use As Is--Data meets its intended end use and can be used without any limitation for that purpose. However, if the data is being used for other purposes outside of what it was collected for, the user of the data should take steps to assure themselves that the information meets their project requirements for accuracy, precision, levels of uncertainty, etc.

- Limited Use--Data is acceptable for its intended use. However, there are limitations as to what conclusions that data can be used to support. If this qualifier is used the limitations for its use must be clearly identified in the report.

- Reject--Data is unacceptable and should not be used in any safety related activity, unless steps are taken to corroborate or confirm the results through aiternate testing.

- Unqualified--Data that has not been collected under a QA program based on the DOE/RW-0333P QAPD and if used for OCRWM related work will have to be qualified in accordance with the requirements in AP6-015 "Control of OCRWM Scientific Investigation Work".

5.5.4.1.5 Data Review. The Cognizant Engineer is responsible to review the test results for technical adequacy and to assure the data obtained meets the intended end use as specified in the DQOS. Data will be reviewed to assure the following:

- SNF requirements, stated procedures, and protocols were correctly followed

- Specifjed holding times were observed for particular tests or samples

- Required QC check samples, method control standards, method blanks, etc. have been performed and the results are within specified limits 


$$
\text { HNF- } y \text { yaC-SD-SNF-PLN-010, Rev. } 1
$$

- Analytical results make sense

- Analytical variability (e.g., precision, accuracy) are within specified tolerances required by the DQOS

- Data anomalies have been addressed

- The data is suitable for its intended use.

Data that is found unacceptable for its intended end use will be identified as such in the test report. In addition, SNF Characterization wi11 have to determine if further sampling and analysis needs to be performed to either confirm or negate the data anomalies found or whether a corrective action $\mathrm{plan}$ is required to reassess the validity of the sampling and analysis strategy used.

This data review will be documented in a test report or data validation report and will be issued as Engineering Support Document in accordance with HNF-PRO-439. This data review report will include:

- The criteria used to evaluate the data

- The results of the review

- Identified discrepancies between the results and the DQO requirements and their impact on data usability

- The conclusions reached as to the acceptability of the data for its intended use.

5.5.4.2 Final Test Reports. Final test reports will be prepared for the fuel and sludge examinations. Tests that fall within the scope of the OCRWM QARD (McCormack 1997) will be qualified using an Independent Technical Review (ITR) process which is equivalent to the OCRWM peer review (Horhota 1997). These reviews directed by DESH will be conducted in accordance with the Administrative Procedure AP6-009-00, OCRWM reviews. ITRs directed by PNNL for reports they prepare wiTl be conducted in accordance with their OCRWM QA plans and procedures. The following sections of this PMP identify the DESH and PNNL reports that will require an ITR to qualify the data.

5.5.4.2.1 Duke Engineering \& Services Hanford Reports for Qualification. Reports to be prepared by DESH that fall within the scope of the OCRWM QARD are listed in Table 2. These reports will be qualified to the QARD with an ITR. Detailed schedules will be prepared for qualification of these reports in FY 1999 consistent with the SNF Project current Multi-Year Program Plan.

\subsection{Pacific Northwest National Laboratory Reports for} Qualification. Reports prepared by the PNNL for the SNF Characterization Project in the following areas fall within the scope of the QARD and are being qualified (McCormack 1997).

- Small sample furnace drying and ignition testing

- Whole element drying studies

- Metallographic examinations of fuel samples

- TGA for oxidation. 


$$
\text { HNK-WHC-SD-SNF-PLN-010, Rev. } 1
$$

Table 2. Duke Engineering \& Services Hanford, Inc. Reports to Be Qualified.

\begin{tabular}{|c|c|}
\hline Report Number & Report Topic \\
\hline \multicolumn{2}{|l|}{ I. Reports Completed } \\
\hline WHC-SD-SNF-TI-012, Rev. 0 & K East Basin Underwater Visual Fuel Survey \\
\hline HNF-SD-SNF-TI-045, Rev. 0 & Visual Examinations of $K$ East Fuel Elements \\
\hline HNF-SD-SNF-TI-046, Rev. 0 & Visual Examinations of $K$ West Fuel Elements \\
\hline \multicolumn{2}{|l|}{ II. Reports in Preparation } \\
\hline$N / A$ & $\begin{array}{l}\text { Analysis of } K \text { West Fuel Internal Sludge and } \\
\text { Surface Coating }\end{array}$ \\
\hline
\end{tabular}

A11 the reports covering these topics have or will receive an ITR and be qualified to the OCRWM QARD. These reports are listed in Table 3 . A percentage of the documents undergoing review will be completed this fiscal year subject to the funding available. The remainder of the documents i isted in Table 3 wi11 be completed in FY 1999 consistent with the SNF Project current Multi-Year Program Plan.

\subsection{HOT CELL EXAMINATIONS}

Hot cell examinations of samples of complete and partial fuel elements, and samples of the sludge, water, and gas contained within the shipping canisters, may all be necessary parts of characterization. PNNL will be responsibie for the examinations within the test facilities. DESH wili provide expert assistance where appropriate.

\subsection{WASTE MANAGEMENT}

A Waste Management P1an was prepared by WHC and PNNL that describes, in detail, the pathway for disposal of all wastes generated from characterization activities (Chastain 1994). DESH will have responsibility for all wastes designated as SNF, and all wastes generated at $K$ Basins. PNNL will have responsibility for disposal of all test residuals generated in their facilities.

\subsection{DATA MANAGEMENT}

A centralized controlled repository of reviewed and pedigree data is a necessary part of the characterization activities. A data 1ibrary will provide ready access to a consistent set of data for all program participants which will be utilized by different individuals for a variety of analysis. The data library will include as much historical data as practical, the test plans and corresponding test instructions, as well as all the raw and reviewed data. 
HNF-WHC-SD-SNF-PLN-010, Rev. 1

Table 3. Pacific Northwest National Laboratory Characterization Reports to be Qualified.

\begin{tabular}{||c|l||}
\hline Report Number & \\
\hline \hline I. REPORTS QUALIFIED \\
\hline PNNL-11438 & $\begin{array}{l}\text { Metall lographic Examination of Damaged N Reactor Spent } \\
\text { Nuclear Fuel Element SFEC5, 4378 }\end{array}$ \\
\hline II. REPORTS COMPLETED UNDERGOING REVIEW \\
(A) Smal1 Sample Drying and Ignition Testing
\end{tabular}


HNF-X⿸广⿰亻寸⿵人一

Data management and development of the centralized data library is a DESH responsibility. Satellite libraries may be created as necessary for operational efficiency. PNNL will be responsible to provide data management for the testing they are conducting for DESH.

\subsection{DATA INTERPRETATION}

Data interpretation is a central part of the plan for characterizing SNF and sludge, and will be a shared DESH and PNNL activity. Individual teams may be formed capitalizing on expertise within each organization for interpretation of individual types of data as well as groups of data addressing specific questions such as extent of fuel oxidation and hydriding, etc. Interpretations and conclusions reached will be conveyed to the SNF Project through the DESH Management Point of Contact (Section 7.1). DESH is responsible for the resolution, to the satisfaction of FDH and RL, of all differences of opinion.

This evaluation will be documented in an Engineering Support Document nd issued in accordance with HNF-PRO-439. This evaluation report will include:

- The criteria and process used to evaluate the data

- The names and qualifications of the reviewers

- The work or data group that was reviewed

- The conclusions of the review

- Any dissenting views or alternate interpretations of the reviewers

- Signature of each of the reviewers or information why a reviewer did not choose to sign.

\subsection{NATIONAL SPENT NUCLEAR FUEL PROGRAM}

The Hanford SNF Project recognizes there is a National SNF Program addressing the issues related to the materials within. the $\mathrm{RL}$ complex. The Hanford SNF Project will participate in the National Program, as authorized by the DESH Management Point of Contact. PNNL will continue to participate in Nationa1 SNF Program Meetings representing its interest as a National Laboratory, but will not represent the SNF Project unless asked. 


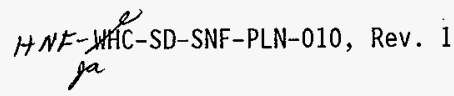

This page intentionally left blank. 
HNF-WHC-SD-SNF-PLN-010, Rev. 1

\subsection{PROGRAM INTERFACES AND COMMUNICATIONS}

\subsection{MANAGEMENT POINTS OF CONTACT}

The Management Point of Contact for DESH is R. P. Omberg, Manager of the SNF Characterization Project.

The Management Point of Contact for PNNL is S. C. Marschman, Lead Scientist for the Radiomaterials Performance Team.

The Management Point of Contact for FDH is E. W. Gerber, Project Manager.

The Management Point of Contact for RL is Jian-Shun Shuen, Characterization Program Staff Engineer.

The Management Points of Contact are the formal interfaces between the organizations. They are responsible for the program interfaces and communications for their respective organizations.

A change in responsibilities for any of these individuals will require written notification to the Management Points of Contact for each of the other organizations.

\subsection{COGNIZANT ENGINEERS, PRINCIPAL INVESTIGATORS, AND TASK TEAM LEADERS}

Cognizant engineers, principal investigators, and task team leaders will be appointed from the DESH and PNNL organizations to fully utilize expertise within each organization for specific activities within the characterization program. These individuals will be identified by the Management Points of Contact within the respective organizations. Appointments to a specific task or activity will be communicated to all interested parties within both organizations. These individuals will act as the single points of contact for that specific task or activity within the characterization program.

\subsection{INTERFACE WITH SNF PROJECTS}

The DESH Management Point of Contact will be the interface and communications link to the SNF Project.

\subsection{INTERFACES WITH OTHER HANFORD PROJECTS}

Single point of contact interfaces will be defined by the FDH and RL Management Point of Contact for other Hanford Projects as appropriate. 


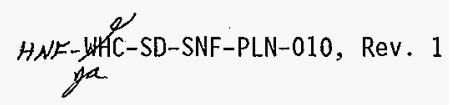

This page intentionally left blank. 


\section{HNF-HÁC-SD-SNF-PLN-010, Rev. I \\ ya}

\subsection{MEETINGS}

\subsection{PERIODIC ACTIVITY MEETINGS}

Periodic activity meetings will be held with appropriate activity participants, as necessary to maintain activities on-schedule. Meetings will be called by the respective cognizant engineer, principle investigator, task team leader, or Management Point of Contact. Weekly meetings on timely activities are encouraged. Meeting minutes are required for a11 meetings, and are the responsibility of the person calling the meeting. The minutes shail be brief and shall be transmitted to all participants and designated management within all organizations no later than two working days after the meeting.

\subsection{TECHNICAL REVIEWS}

Technical reviews will be the responsibility of the DESH Management Point of contact and will be held to cover technical progress. The timing, locations and agenda for the reviews will be established by the Management Points of Contact. Attendance will be by invitation and may include off-site as well as on-site SNF Program participants. The intent of the technical reviews is to obtain timeiy peer reviews of significant progress and results. 
HNF- HAC-SD-SNF-PLN-010, Rev. 1

This page intentionally left blank. 


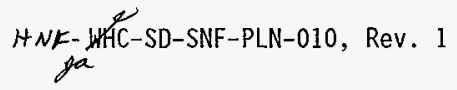

\subsection{REPORTS AND DOCUMENTATION}

\subsection{TOPICAL REPORTS AND OPEN LITERATURE PUBLICATIONS}

Timely reports at the completion of an activity are required of the organization with the primary responsibility or lead for that activity. Preparation of topical reports are encouraged, however, letter reports may be acceptable on a limited basis for small activities or for timely distributions of results. Open literature pubiications within the appropriate forum are encouraged. Open literature publications must have SNF Project approval prior to release from the respective organizations.

\subsection{PLAN, REQUIREMENTS, ROUT INE CORRESPONDENCE}

Examination plans, data requirements, and routine correspondence generated within the characterization activities will be made available to a11 interested parties. In order to expedite the document approval process, early drafts and parallel reviews will occur without regard to organization. The intent is to provide free and timely exchanges of information to a11 interested parties. 
HNF-WKC-SD-SNF-PLN-010, Rev. 1

This page intentionally left blank. 


\section{HNF-SHC-SD-SNF-PLN-010, Rev. 1 \\ pa}

\subsection{SCHEDULES AND COMMITMENTS}

\subsection{OVERALL PROJECT SCHEDULES}

The overall project schedules are structured around the SNFP Path Forward strategy for removal of fuel and sludge from the $K$ Basins. A key element in this is the integrated schedule for $K$ Basin activities and projects. Also included are completion of the EIS/ROD, completion of the safety analysis reports, completion of drying, and interim storage of the fuel, and removal of the sludge.

\subsection{CHARACTERIZATION PROGRAM SCHEDULE AND MILESTONES}

Activity and milestone schedules have been established in the MYPP and in the Plan for Characterization of $\mathrm{K}$ Basin SNF and Sludge. These schedules are fully responsive to the overall project schedules. Task schedules will be reconciled by the Management Points of Contact to satisfy the overall project milestones and deliverables, and will be made available to all the Management Points of contact and to the working level organizations to fully integrate activities to meet established milestones. 
HNF- WHC-SD-SNF-PLN-010, Rev. 1

gá

This page intentionally left blank. 


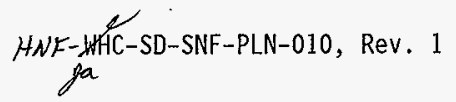

\subsection{FUNDING}

The identification and allocation of funds for characterization activities will be provided through the SNF Project MYPP Documentation. 


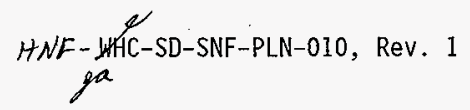

This page intentionally left blank. 


\section{HNF- HHC-SD-SNF-PLN-010, ReV. 1 \\ ya}

\subsection{PROGRAM MANAGEMENT PLAN REVISIONS}

The intent of this PMP is to set the framework for the plan to characterize the SNF and sludge at Hanford with initial focus on the K Basins. If there is a significant revision in the Project work scope and the defined responsibilities of DESH and PNNL, a revision to this PMP will be prepared. Changes to the PMP and associated plans will be managed through formal change control and reference baseline management documents. 
HNF-

This page intentionally left blank. 


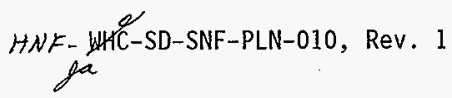

\subsection{REFERENCES}

Chastain, S. A., and R. L. Spinks, 1994, Waste Management Plan for Hanford Spent Nuclear Fuel Characterization Activities, WHC-SD-SNF-PLN-001, Rev. 0, Westinghouse Hanford Company, Richland, Washington.

EPA, 1993, "Guidance for Planning for Data Collection in Support of Environmental Decision Making Using the Data Quality objectives Process," EPA QA/G-4 Interim Final, U.S. Environmental Protection Agency, Washington, D.C.

Horhota, M. J., 1997, Quality Assurance Implementation Plan for Spent Nuclear Fue7 Characterization, HNF-SD-SNF-IMP-001, Rev. 0, Duke Engineering \& Services Hanford, Inc., Richland, Washington.

Lawrence, L. A., 1998, Strategy for Phase II Whole Element Furnace Testing $K$ West Fue7, HNF-2315, Rev. 0, Duke Engineering \& Services Hanford, Inc., Richland, Washington.

Lawrence, L. A., 1997a, Letter to S. C. Marschman, PNNL, "Transmittal of Duke Engineering \& Services Hanford, Inc. Audit Report," DESH-9759901, Duke Engineering \& Services Hanford, Inc., Richland, Washington.

Lawrence, L. A., 1997b, Strategy for Examination of the Fifteen $K$ West Basin Fue7 E7ements, HNF-SD-SNF-SP-018, Rev. 0, Duke Engineering \& Services Hanford, Inc., Richl and, Washington.

Lawrence, L. A., 1996, Strategy for Examination of the Initial Nine K East Basin Fuel Elements, WHC-SD-SNF-SP-014, Rev. 0, Westinghouse Hanford Company, Richland, Washington.

Lawrence, L. A., and S. C. Marschman, 1995, P7 an for Characterization of $K$ Basin Spent Nuclear Fue7 and S7udge, WHC-SD-SNF-PLN-007, Rev. 1, Westinghouse Hanford Company, Richland, Washington.

Lawrence, L. A., K. S. Redus, and T. A. Thornton, 1994, Spent Nuclear Fue7s Project Characterization Data Qua7ity Objectives Strategy, WHC-EP-0795, Westinghouse Hanford Company, Richland, Washington.

McCormack,, R. L., 1997, Application of the Office of Civilian Radioactive Waste Management Quality Assurance Requirements to the Hanford Spent Nuclear Fuel Project, HNF-SD-SNF-RPT-007, Rev. 1, Duke Engineering \& Services Hanford, Inc., Richland, Washington.

SelTers, E. D., 1995, Letter to President WHC, "Office of Civilian Radioactive Waste Management (OCRWM), "Quality Assurance Requirements and Description (QARD), RW-033P, 95-SFD-098, Westinghouse Hanford Company, Richland, Washington. 


\section{DISTRIBUTION SHEET}

\begin{tabular}{|c|c|c|c|c|c|}
\hline \multirow{2}{*}{$\begin{array}{l}\text { To } \\
\text { Distribution }\end{array}$} & \multirow{2}{*}{\multicolumn{3}{|c|}{$\begin{array}{l}\text { From } \\
\text { SNF Characterization Project }\end{array}$}} & \multicolumn{2}{|l|}{ Page 1 of 2} \\
\hline & & & & \multicolumn{2}{|c|}{ Date May 1998} \\
\hline \multicolumn{4}{|l|}{ Project Title/Work Order } & \multicolumn{2}{|l|}{ EDT No. } \\
\hline \multicolumn{4}{|c|}{$\begin{array}{l}\text { Characterization Program Management Plan for Hanford K Basin } \\
\text { Spent Nuclear Fuel, } 4 \text { W }\end{array}$} & \multicolumn{2}{|c|}{ ECN No. 614818} \\
\hline Name & MSIN & $\begin{array}{l}\text { Text } \\
\text { With All } \\
\text { Attach. }\end{array}$ & Text Only & $\begin{array}{l}\text { Attach./ } \\
\text { Appendix } \\
\text { Only }\end{array}$ & $\begin{array}{l}\text { EDT/ECN } \\
\text { Only }\end{array}$ \\
\hline
\end{tabular}

Fluor Daniel Hanford, Inc.

E. W. Gerber

R3-11 $X$

Duke Engineering \& Services Hanford, Inc.

R. B. Baker

P. E. Davis

J. R. Frederickson

L. A. Lawrence (5)

B. J. Makenas

R. P. Omberg

R. P. Ruth

A. M. Segrest

D. W. Smith

J. A. Swenson

J. H. Wicks

SNF Project Files
HO-40

R3-11

R3-86

HO- 40

$\mathrm{HO}-40$

HO- 40

R3-11

R3-11

R3-11

R3-11

$\times 3-74$

R3-11

$x$
$x$
$x$
$x$
$x$
$x$
$x$
$x$
$x$
$x$
$x$
$x$

Duke Engineering \& Services Northwest, Inc.

M. J. Horhota

B1-13

$x$

Lockheed Martin Services, Inc.

Central Files

B] -07

$x$
$x$

Pacific Northwest National Laboratory

J. M. Latkovich

$\mathrm{Kg}-44$

P7-27

S. C. Marschman

P7-27

$x$
$x$
$x$

U.S. Department of Energy,

Richland Operations office
R. M. Hiegel
P. G. Loscoe
E. D. Sellers
J. Shuen

$\begin{array}{ll}\text { S7-41 } & X \\ \text { S7-41 } & X \\ \text { S7-41 } & X \\ \text { S7-41 } & X\end{array}$

